University of Nebraska - Lincoln

DigitalCommons@University of Nebraska - Lincoln

1987

\title{
Harvest of Grief: The Grasshopper Plagues and Public Assistance in Minnesota, 1873-78
}

Gary D. Olson

Augustana College, Sioux Falls

Follow this and additional works at: https://digitalcommons.unl.edu/greatplainsquarterly

Part of the Other International and Area Studies Commons

Olson, Gary D., "Harvest of Grief: The Grasshopper Plagues and Public Assistance in Minnesota, 1873-78" (1987). Great Plains Quarterly. 340.

https://digitalcommons.unl.edu/greatplainsquarterly/340

This Article is brought to you for free and open access by the Great Plains Studies, Center for at DigitalCommons@University of Nebraska - Lincoln. It has been accepted for inclusion in Great Plains Quarterly by an authorized administrator of DigitalCommons@University of Nebraska - Lincoln. 
try. The western frontier also experienced a second calamity that, with cruel irony, recurred each year for the duration of the depression. This calamity, the grasshopper infestation, is the subject of this book. The author has focused her attention upon the "grasshopper plagues and public assistance in Minnesota" from 1873-1878. It is her purpose to study "the response to the plagues personally, locally, and at the state and national levels" in order to understand attitudes, and to examine the relationship between farm people and their government. The author argues that the general unresponsiveness of local, state, and national government to the victims of this natural disaster reflects the triumph of the "money ethic" over the work ethic in nineteenth century America and is evidence that an earlier cultural value attached to farming and farmers no longer predominated in American society. The argument is unconvincing, in large part because in examining the regional grasshopper calamity the author has totally neglected the national economic one.

On the descriptive level this study does quite well. The author outlines the general dimensions of the grasshopper plague of the 1870 s, describes the insects and their life-cycle of crop destruction, and, using diaries and correspondence of grasshopper victims and newspaper accounts, narrates the impact of the grasshoppers on the lives and aspirations of the frontier farmers of southwestern Minnesota.

The bulk of the volume is given to tracing the response of government at all levels to pleas for assistance from the grasshopper victims. This is both the strongest and the weakest portion of the book, for the research is extensive while its scope is narrow. Government aid was generally reluctant and always inadequate. The variations in farmers' circumstances and the uneven destruction from year to year made government officials unsure about the extent of real need and the most appropriate form of assistance. Consequently, governments extended tax deadlines and payment deadlines on preemption land contracts, 
provided seed grain, and even distributed surplus military clothing, but appropriated and distributed little money. Even then, elaborate documentation of destitution was required.

Atkins's contention that the lack of compassion and generosity of Minnesota and national government officials was solely due to "a set of attitudes about the poor and the causes of poverty" is so narrow it is unconvincing. The author argues that governmental unresponsiveness illustrates a cultural conflict in which "success would come to be measured more by wealth than by nobility of occupation," and cites evidence of this point of view in the words of key officials and newspaper editors. She does not mention the depression of 1873 nor its impact upon the ability of government to respond to the grasshopper sufferers. Nor does she mention the reluctance of real estate interests, who tended to dominate local and state government, to publicize the plight of settlers for fear of scaring off prospective settlers and depressing land value even further. She does not discuss the role of nineteenth-century government in society nor government's limited financial means in an era before income and sales taxes. Although she points to instances where government did assist victims of natural disasters (notably the Chicago fire of 1871), she seems to imply that aid was the norm for the nineteenth century. One could argue that it was exceptional that any aid was given to grasshopper victims rather than that so little was given.

The volume is attractive, well written, and includes appropriate maps and illustrations, but it is neither a complete account of the grasshopper plague in Minnesota in the 1870s nor a successful piece of intellectual history. It comes closer to the former than the latter, but the author's narrow argument would have been more appropriately made in an article.

GARY D. OLSON

Department of History Augustana College, Sioux Falls 